\title{
A comparison of ground beetle assemblages (Coleoptera: Carabidae) in conventionally and ecologically managed alfalfa fields
}

\author{
P. Kolařík, J. Rotrekl, ${ }^{1}$ M. Barták, ${ }^{2}$ A. Krupauerová, ${ }^{2}$ J. Frydrych ${ }^{3}$ \\ ${ }^{1}$ Department of Plant Protection, Agriculture Research Ltd., Troubsko; ${ }^{2}$ Department of Zoology \\ and Fisheries, Czech University of Life Science, Prague; ${ }^{3}$ OSEVA Research and Development Ltd., \\ Zubří, Czech Republic
}

\begin{abstract}
From 2007-2011, the occurrence of ground beetles (Coleoptera: Carabidae) was studied using emergence traps in two differently managed alfalfa fields in the Czech Republic - a conventional and an ecological production system. In total, 784 specimens of ground beetles representing 58 species were trapped in these two alfalfa fields in South Moravia. A slightly higher number of specimens were trapped in the conventionally managed than in the ecological alfalfa stand (404 vs 380 , respectively). In the conventionally managed alfalfa stand, the number of species was also higher than in the ecological stand (45 vs 40, respectively). With the exception of 2007 and 2009, Simpson's indices of diversity were higher in the conventional stand than in the ecological in all study years. Shannon's index was higher in the conventional alfalfa field in 2008, 2009, and 2011. Regarding distribution, species classified into group E (i.e., those without special demands on the type and quality of their habitat) dominated in both types of management throughout the experimental period. The incidence of species classified into group $\mathrm{R}$ (i.e., those with narrow ecological amplitude) was very low; i.e., only four species. These ground beetle species are included in the Red List of Threatened Species of the
\end{abstract}

Correspondence: Pavel Kolařík, Department of Plant Protection, Agriculture Research Ltd., Troubsko, Czech Republic.

Tel.: +420.547138835 - Fax: +420.547138800 .

E-mail: kolarik@vupt.cz

Key words: Coleoptera, Carabidae, agriculture, ecological alfalfa, conventional alfalfa.

Funding: this research was supported by the NAZV project $\mathrm{QH} 72151$ of the Czech Ministry of Agriculture.

Received for publication: 16 April 2014.

Revision received: 16 June 2014.

Accepted for publication: 20 June 2014.

(C) Copyright P. Kolař́k et al., 2014

Licensee PAGEPress, Italy

Journal of Entomological and Acarological Research 2014; $46: 3791$

doi:10.4081/jear.2014.3791

This article is distributed under the terms of the Creative Commons Attribution Noncommercial License (by-nc 3.0) which permits any noncommercial use, distribution, and reproduction in any medium, provided the original author(s) and source are credited.
Czech Republic, and all of them (i.e. Acupalpus suturalis, Calosoma auropunctatum, Cicindela germanica and Ophonus cribricollis) are listed as vulnerable.

\section{Introduction}

Ground beetles (Carabidae) are considered one of the most important bio-indicator groups of organisms and are often used to assess natural and altered habitats (Holland, 2002). The main reason for use of ground beetles as bio-indicators is the ease of monitoring and popularity of these insects, together with the availability of checklist and determination literature. The first review of ground beetles of the Czech Republic was published by Kult (1947) and was followed by species lists by Pulpán \& Reška (1971), Pulpán \& Hůrka (1993) and Hůrka (1996). Hůrka et al. (1996) published a very important paper dealing with the bio-indication of individual species, the methodology of which was focused more on agricultural habitats. This trend of monitoring of agricultural habitats can be seen in foreign studies, of which the most important is probably the summary published by Holland (2002). The literature regarding recognition of protected areas and their beetle fauna is considerably more deficient. Complex studies on ground beetles from small areas have been practically non-existent until recently (Niedobová et al., 2011). Our study focuses on the monitoring of the variability of ground beetles (Coleoptera: Carabidae) under two various management systems in agricultural land (intensive agricultural and ecologically managed agricultural systems).

Ground beetles represent an important ecological group of insects that play an important role as predators in the life cycle of both invertebrate and vertebrate species in all ecosystems. Because of their response to environmental changes, they are very suitable biological indicators of environmental change. Ground beetles respond sensitively to various toxic substances (e.g., insecticides, herbicides, etc.) that are imported into biological communities for the purpose of killing various pests, and also to excessive doses of industrial fertilizers. For these reasons, the species Zabrus tenebrioides (which is the only representative important pest carabid in the country's warmer regions) practically disappeared from Czech fields. Many members of the Carabidae are also sensitive to changes in $\mathrm{pH}$ and, above all, humidity, so they can be used as bio-indicators of environmental changes. This family has the highest number of species in the world, numbering approximately 40,000 (Boháč 1999; Arnett \& Thomas, 2001; Arndt et al., 2005; Thayer, 2005). Ground beetles occur in practically all kinds of terrestrial ecosystems and represent an important component of the soil fauna. Because of their species versatility, abundance and usefulness, ground beetles are an important group of predators that contribute to the maintenance of biological balance within the framework 
of forest ecosystems (Lövei \& Sunderland, 1996). According to the provisions of the Act no. 114/1992 Coll., large beetles that are members of the genera Carabus, Calosoma and Cicindela belong to a group of threatened species and are therefore protected (Anonymous, 2006).

In the Czech Republic, the family Carabidae, with approximately 530 species, is ranked as the third most abundant taxon (Hưrka, 1996). According to Veselý (2002), there are approximately 504 species of ground beetles still present in the territory of the Czech Republic. Half of them live in the leaf litter and represent an important component of soil fauna. The main reasons these beetles are considered to be sensitive bioindicators of anthropogenic environmental change are that there exists a good knowledge of the ecological requirements of the majority of Central European species, and members of this family occur in all semi-natural and man-modified ecosystems (Boháč, 1988, 1999; Hůrka et al., 1996). Information on the distribution of ground beetle species in the Czech Republic was published by Skoupý (2004). The dominant group are epigeic species living on the soil surface, below stones and in topsoil layers. It is also known that they are distributed spatially, at different altitudes; i.e., from lowlands to alpine regions (Pulpán \& Reška, 1971; Kula \& Purchart, 2004). The Carabidae includes predominantly non-specialized predators that either actively chase their prey or consume cadavers of dead animals, including both invertebrates (living primarily in soil; e.g., arthropods, annelids and molluscs) and vertebrates (Larochelle, 1990).

In the Czech Republic, the landscape is very uniform and the biodiversity of plant and animals is relatively low. Fortunately, there are some niches where it is possible to observe the occurrence of some new species. However, these species are not actually new, but rather lost, meaning that previously they were quite abundant, but more recently were driven out due to the development of large-scale (i.e., intensive) farming, involving the growing of only a few crops on large blocks of agricultural land, and also the use of heavy machinery and application of very high doses of different chemicals (Nováková, 2012).

Agriculture is one of the most important domains of human activity and therefore can have crucial effects on the appearance, exploitation, and management of the cultural landscape. Its main focus is, above all else, the production of high quality raw materials for the food industry. For this reason, it is often noted that biodiversity is diminishing in agricultural areas and that some (in this case, insect) species can predominate in existing natural ecosystems (Kolařík et al., 2010). Maximisation of production and profit has been the main objectives in the development of conventional agriculture. Worldwide, this intensification is based on six main pillars; viz., intensive tillage, growing of monoculture crops, irrigation, application of chemical/mineral fertilizers, chemical methods of plant protection and, recently, also genetic manipulation. Together they create a system, in which one pillar is dependent on the other and enforces or intensifies the necessity of all the others (Urban and Šarapatka, 2003). Methods of organic farming support and improve the biodiversity of natural biotopes because they help to create more diversified living conditions, offer better conditions for reproduction and propagation of individual species, increase the supply of nutrients, etc. This is a system that is more focused on problems of environmental and landscape protection. On organically managed arable land, in permanent grassland, field margins, and neighbouring biotopes, the biodiversity of both flora and fauna is greater than in conventional farming. Additionally, the diversity of crops cultivated under organic production is higher than on conventionally managed farms (Šarapatka and Urban, 2005).

\section{Materials and methods}

Insect associations were monitored in two localities situated in the South Moravian Region of the Czech Republic, Hustopeče and Sedlec. In the former, insect trapping was conducted in a conventionally man- aged alfalfa stand where pesticides were applied; the second cut was not made, and the stand was used instead for production of seed material. Ecologically managed alfalfa crops were grown in localities in Sedlec (2007 and 2011) and Březí (2008, 2009, and 2010).

The locality of Hustopeče ( $48^{\circ} 57.906 \mathrm{~N}, 016^{\circ} 42.738 \mathrm{E}, 199 \mathrm{~m}$ asl) can be characterized as an arid maize-growing region with a typical continental climate. The long-term average annual temperature and total precipitation were $9.2^{\circ} \mathrm{C}$ and $545 \mathrm{~mm}$, respectively. The soil types are classified as chernozem and orthic luvisol, respectively. In terms of botanical characterisation, the stand was an alfalfa monoculture that was free of weeds during all years of the study period. At the beginning of or during the course of the growing seasons, herbicides were applied to maintain the stand's weed-free status. Starting prior to flowering and continuing to the end of the stand's growth, insecticide treatments comprising various active agents (e.g., neonicotinoids, pyrethroids) were applied to protect the plants against sucking Heteroptera. Before harvest, the crop was desiccated using a broad spectrum herbicide.

The ecologically managed alfalfa stands were cultivated without the application of fertilisers or pesticides. In 2007 and 2011, monitoring was conducted at the Sedlec site $\left(48^{\circ} 45.961 \mathrm{~N}, 016^{\circ} 42.738 \mathrm{E}, 204 \mathrm{~m}\right.$ asl). This locality is also classified as an arid maize-growing region having a typical continental climate. The soil is classified as degraded chernozem with a pH of 7.2. The humus content at the depth of the plowing layer $(25 \mathrm{~cm})$ was $2.6 \%$. In botanical terms, the stand was an alfalfa monoculture with a good canopy and a minimal weed infestation. This stand was established in 2007.

In 2008, 2009 and 2010, monitoring was conducted at the Březí site (4848'43.407” N, 16³3'13.385” E, $187 \mathrm{~m}$ asl). The distance from Březí to Sedlec was $6 \mathrm{~km}$. This change of the locality was necessitated by the fact that the original alfalfa stand had to be plowed in. In Sedlec and Březí, ecological production was implemented starting in 2002. The long-term average annual temperature and average temperature during the growing season were $9.2^{\circ} \mathrm{C}$ and $15.6^{\circ} \mathrm{C}$, respectively. The longterm total annual precipitation and the total precipitation during the growing season were $479.7 \mathrm{~mm} 305.8 \mathrm{~mm}$, respectively. This site is also classified as an arid maize-growing region with a typical continental climate. The soil is classified as degraded chernozem with a pH of 7.2. The humus content of humus at the depth of the plowing layer $(25 \mathrm{~cm})$ was $2.6 \%$. In botanical terms, the stand was an alfalfa monoculture with a very rich spectrum of weeds. Various weeds were identified; e.g., Matricaria recutita, Tripleurospermum maritimum, Matricaria maritime, Elytrigia repens, Capsella bursa-pastoris, Taraxacum officinale, Papaver rhoeas, Sonchus arvensis, Artemisia vulgaris, Descurainia sophia, Viola arvensis, Apera spica-venti, etc.

To capture only autochthonous species and simultaneously achieve high taxonomic resolution, we used emergence traps. In 2007, the emergence traps were distributed in monitored localities from 3 July to 2 October (a total of three samples were taken during this period). In 2008, sampling was conducted from 28 April to 1 October (a total of five samples were taken). In 2009, emergence traps were distributed in individual localities from 21 April to 8 October (a total of six samples were taken). In 2010, emergence traps were distributed in fields from 3 May to 3 September (a total of five samples were taken) and in 2011 from 2 May to 4 October (a total of five samples were taken).

Traps (1 trap per site) of a quadrangular pyramid shape (effective capture area=trap bottom $=1 \mathrm{~m}^{2}$ ) were made of fine polyamide fabric $(<0.1 \mathrm{~mm}$ mesh). Sides of the trap were shallowly buried in the soil to prevent entry of allochthonous immigrants. The collection head was filled with $70 \%$ ethyl alcohol. Approximately each month, the trapped material was collected by simply inserting a new collecting bottle, and the old one was taken for storage in a freezer box $\left(20^{\circ} \mathrm{C}\right)$. When emptying traps, we changed the trap location to minimise location effects and to avoid unnecessary replication, which, according to our preliminary experiments, adds little additional information for this relatively 
large sampling area. Therefore, in the course of this experiment, we monitored about $5 \mathrm{~m}^{2}$ at each locality/year.

All specimens of Carabidae were dry prepared by direct pinning from the alcohol, and identified using keys by Kult (1947), Hůrka (1992, 1996), Frede (1976) and other sources. The nomenclature used was according to Audisio \& Taglianti (2011).

Individual species were classified according Hůrka et al. (1996) into three distribution/ occurrence groups ( $\mathrm{R}, \mathrm{A}$ and $\mathrm{E}$ ) according to the extension of ecological valence of taxa and their relation to habitat. Group E consists of eurytopic species with no special demands on habitat type and quality. Species from modified habitats, species inhabiting strongly anthropogenically influenced landscapes, and expansive species belong to this group. Group A includes more adaptable species, which are found in more or less natural habitats. This group consists mainly of species typical of forests, meadows, and pastures, and coastal species from standing and flowing water. Species in group $\mathrm{R}$ are those having narrow ecological amplitude, and which currently exhibit the characteristic traits of the group. These are rare and endangered species, occurring naturally in undisturbed ecosystems.

Shannon-Weaver's index of diversity $\left(H=-\Sigma p_{i} \cdot \log p_{i}\right)$ and Simpson's index of diversity $\left(D=1 / \Sigma p_{i}^{2}\right)$ were calculated, where $\mathrm{p}_{\mathrm{i}}=\mathrm{N}_{\mathrm{i}} / \mathrm{N}, \mathrm{N}=$ number of specimens of the locality, and $\mathrm{N}_{\mathrm{i}}=$ number of specimens of the species in the locality.

\section{Results and discussion}

At the locality growing conventionally managed alfalfa, the numbers of species of Carabidae and total specimens caught each year were: 2007, 5 species, 15 specimens; 2008, 20 species, 119 specimens; 2009, 30 species, 148 specimens; 2010, 12 species, 34 specimens; and 2011, 17 species, 90 specimens. At the locality growing ecologically managed alfalfa, the numbers were: 2007, 7 species of Carabidae, 10 specimens; 2008, 21 species, 119 specimens; 2009, 20 species, 55 specimens; 2010, 11 species, 73 specimens; and 2011, 19 species, 130 specimens caught (Table 1).

In terms of distributional groups, the conventional alfalfa stand was dominated during the $2007-2011$ period by species in group E (70.2\%), $25.5 \%$ were species in group A, and $4.3 \%$ belonged to group R. Species

Table 1. Ground beetles (Carabidae) collected in two differently managed alfalfa stands (South Moravia, 2007-2011).

\begin{tabular}{|c|c|c|c|c|c|c|c|c|c|c|c|}
\hline \multirow[t]{2}{*}{ Species } & \multirow[t]{2}{*}{ IS } & \multicolumn{5}{|c|}{ Conventional stand } & \multicolumn{5}{|c|}{ Organic stand } \\
\hline & & $\mathrm{T} 1$ & $\mathrm{~T} 2$ & T3 & T4 & T5 & $\mathrm{T} 1$ & $\mathrm{~T} 2$ & T3 & $\mathrm{T} 4$ & T5 \\
\hline Acupalpus meridianus (Linnaeus, 1761) & $\mathrm{E}$ & & 4 & 4 & 1 & & & 3 & 7 & & \\
\hline Acupalpus suturalis (Dejean, 1829) & $\mathrm{R}$ & & & 4 & 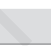 & & & 1 & 2 & & \\
\hline Acupalpus interstitialis (Reitter, 1884) & $\mathrm{R}$ & & & 8 & 3 & & & & & 2 & \\
\hline Acupalpus meridianus (Linnaeus, 1761) & $\mathrm{E}$ & & & 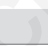 & 6 & & & & & 19 & 1 \\
\hline Amara aenea (De Geer, 1774) & $\mathrm{E}$ & & 2 & 3 & & & & & & & \\
\hline Amara apricaria (Paykull, 1790) & $\mathrm{E}$ & & & & & & 1 & 1 & & & \\
\hline Amara aulica (Panzer, 1797) & $\mathrm{E}$ & & 3 & & & 1 & & & & 1 & 2 \\
\hline Amara bifrons (Gyllenhal, 1810) & $\mathrm{E}$ & & & & & & & 4 & 2 & 30 & 2 \\
\hline Amara convexiuscula (Marsham, 1802) & $\mathrm{E}$ & 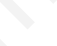 & 1 & 1 & & & & & & & \\
\hline Amara familiaris (Duftschmid, 1812) & $\mathrm{E}$ & & & 6 & 5 & & & & & & 1 \\
\hline Amara littorea (Thomson, 1857) & $\mathrm{E}$ & & & & & & & 1 & 1 & 1 & \\
\hline Amara montivaga (Sturm, 1825) & $\mathrm{E}$ & & & 3 & & & & & & & \\
\hline Amara ovata (Fabricius, 1792) & $\mathrm{E}$ & & & 5 & & & & & & & \\
\hline Amara similata (Gyllenhal, 1810) & $\mathrm{E}$ & & & 35 & & 1 & & 1 & 1 & & 1 \\
\hline Anchomenus dorsalis (Pontoppidan, 1763) & $\mathrm{E}$ & & 4 & 10 & & 15 & & & & & 7 \\
\hline Anisodactylus signatus (Panzer, 1797) & $\mathrm{E}$ & & & & & & & 4 & 1 & & \\
\hline Bembidion lampros (Herbst, 1784) & $\mathrm{E}$ & & 5 & & & 1 & & & & & \\
\hline Bembidion quadrimaculatum (Linnaeus, 1761) & $\mathrm{E}$ & & 1 & & & & & & & & \\
\hline Bembidion properans (Stephens, 1828) & $\mathrm{E}$ & & & & & 10 & & & 1 & 3 & 1 \\
\hline Brachinus explodens (Duftschmid, 1812) & $\mathrm{E}$ & & 1 & 4 & 3 & & & 1 & 2 & & \\
\hline Calathus erratus (C.R. Sahlberg, 1827) & $\mathrm{A}$ & 1 & 5 & & & & 1 & & & & 1 \\
\hline Calathus fuscipes (Goeze, 1777) & $\mathrm{E}$ & 1 & 1 & & & & 2 & 3 & & 3 & 27 \\
\hline Calathus melanocephalus (Linnaeus, 1758) & $\mathrm{E}$ & & & 1 & & & & & & & \\
\hline Carabus cancellatus (Illiger, 1798) & A & & & & & & 1 & & & & \\
\hline Calosoma auropunctatum (Herbst, 1784) & A & & & 1 & & & & & & & 1 \\
\hline Cicindela germanica (Linnaeus, 1758) & A & & & 1 & 2 & 3 & & 1 & 1 & 8 & 2 \\
\hline Dolichus halensis (Schaller, 1783) & $\mathrm{E}$ & & & & & & & & & & 7 \\
\hline Demetrias monostigma (Samouelle, 1819) & A & & 5 & 2 & & 3 & & & 1 & & \\
\hline Demetrias atricapillus (Linnaeus, 1758) & $\mathrm{E}$ & & & & 2 & & & & & & \\
\hline Harpalus affinis (Schrank, 1781) & E & & 4 & 2 & & & & 1 & 3 & 2 & 3 \\
\hline
\end{tabular}


in group $\mathrm{E}$ were also dominant in the ecologically managed alfalfa (67.5\%), $25 \%$ of the species were in group A, and $7.5 \%$ of the species were in group R. Using purely qualitative criteria (ratio of E:A species), we found 33:12 (=2.75) for conventional alfalfa and 27:10 (=2.70) for ecological alfalfa. This ratio should be greater in more disturbed habitats, and according to our previous studies, can reach values of approximately 1.0 (or even less) in habitats close to the natural state; values higher than 3 indicate early successional (or heavily disturbed) sites. Slightly less disturbed habitats are represented in alfalfa plantings employing ecological methods than those using conventional methods.

Additionally, we also found four species of Carabidae included in the Red List of Threatened Species of the Czech Republic (Veselý et al., 2005). All of the species found were listed as vulnerable (Acupalpus suturalis, Calosoma auropunctatum, Cicindela germanica and Ophonus cribricollis). It is significant that these species were trapped not only in the locality with the ecological alfalfa stand, but also in the conventional stand (i.e., the locality where pesticides were applied), where their numbers were even higher. Turin et al. (2003) mentioned that the destruction and fragmentation of biotopes, as well as the application of insecticides, were the most important factors influencing the size of ground beetle populations. The anthropogenous pressure (i.e., increased visits by vacationers) may also function as a negative factor. Gryuntal (1991) found that the numbers of trapped specimens decreased in strongly disturbed sites, although the number of species detected remained unchanged. In this study, a total of 784 specimens of ground beetles (Carabidae) representing 58 species were found using emergence traps in southern Moravia alfalfa fields. Slightly higher numbers of specimens were observed in conventional alfalfa (404) than in ecologically managed alfalfa (380). A higher number of species was observed in conventionally managed alfalfa (45) than in ecologically managed alfalfa (40). Simpson's index of diversity was higher on conventional alfalfa in all years except 2007 and 2009. Shannon's index was higher on conventional alfalfa in 2008, 2010 and 2011 (Table 2).

The responses of Carabidae to industrial pollution vary greatly, and for this reason it is difficult to specify its effects, because site and climate also play some role (Stubbe \& Tietze, 1982). Common thermophilous- and xerophilous species of ground beetles predominated in both localities. They occurred most frequently in field margins, in fallows, rocky steppes, shrubby slopes and in ruderal sites. The most abundant species were: Pseudoophonus rufipes (107 specimens), Trechus quadristriatus (107 specimens) and Poecilus cupreus (67 specimens). Another abundant group involved species that in individual

Table 1. Continued from previous page.

\begin{tabular}{|c|c|c|c|c|c|c|c|c|c|c|c|}
\hline \multirow{2}{*}{ Species } & \multirow[t]{2}{*}{ IS } & \multicolumn{5}{|c|}{ Conventional stand } & \multicolumn{5}{|c|}{ Organic stand } \\
\hline & & $\mathrm{T} 1$ & $\mathrm{~T} 2$ & $\mathrm{~T} 3$ & $\mathrm{~T} 4$ & T5 & T1 & $\mathrm{T} 2$ & T3 & $\mathrm{T} 4$ & T5 \\
\hline Harpalus distinguendus (Duftschmid, 1812) & $\mathrm{E}$ & & 4 & 4 & & & 2 & 1 & & & 20 \\
\hline Harpalus signaticornis (Duftschmid, 1812) & $\mathrm{E}$ & & & & & & & 12 & & & \\
\hline Harpalus smaragdinus (Duftschmid, 1812) & $\mathrm{A}$ & & & - & & & & & & & 1 \\
\hline Harpalus rubripes (Duftschmid, 1812) & E & & & 1 & & & & & & 3 & \\
\hline Leistus ferrugineus (Linnaeus, 1758) & $\mathrm{E}$ & & & & & 6 & & & & & \\
\hline Lionychus quadrillum (Duftschmid, 1812) & A & 6 & 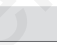 & & & & 1 & & & & \\
\hline Loricera pilicornis (Fabricius, 1775) & $\mathrm{E}$ & & & & & 1 & & & & & \\
\hline Microlestes maurus (Sturm, 1827) & $\mathrm{E}$ & ta & 5 & & & & & & & & \\
\hline Microlestes minutulus (Goeze, 1777) & $\mathrm{E}$ & & 1 & 3 & 3 & & & & 3 & & \\
\hline Notiophilus pusillus (G.R. Waterhouse, 1833) & $\mathrm{E}$ & & 6 & 1 & 3 & 2 & & 3 & & & \\
\hline Ophonus azureus (Fabricius, 1775) & $\mathrm{E}$ & & & & & & & & & 1 & \\
\hline Ophonus cribricollis (Dejean, 1829) & $\mathrm{R}$ & & & & & & & & 4 & & \\
\hline Ophonus rufibarbis (Fabricius, 1792) & $\mathrm{E}$ & & & 3 & & 1 & & & 1 & & \\
\hline Paradromius linearis (Olivier, 1795) & $\mathrm{E}$ & & & 2 & & & & & & & \\
\hline Paratachys bistriatus (Duftschmid, 1812) & $\mathrm{A}$ & & & 2 & & 1 & & & 2 & & 1 \\
\hline Poecilus cupreus (Linnaeus, 1758) & E & & 25 & 4 & & 25 & & 4 & 2 & & 7 \\
\hline Poecilus versicolor (Sturm, 1824) & $\mathrm{E}$ & & & & 1 & & & & & & \\
\hline Pseudoophonus griseus (Panzer, 1797) & E & & & 1 & & 2 & & & & & \\
\hline Pseudoophonus calceatus (Duftschmid, 1812) & A & & & 1 & & & & & & & \\
\hline Pseudoophonus rufipes (De Geer, 1774) & E & 4 & 16 & 9 & 4 & 10 & 2 & 24 & 7 & & 31 \\
\hline Pterostichus longicollis (Duftschmid, 1812) & A & & & 2 & & & & & & & \\
\hline Pterostichus niger (Schaller, 1783) & A & & & & & & & 1 & & & \\
\hline Pterostichus vernalis (Panzer, 1796) & A & & & 1 & & & & & & & \\
\hline Stenolophus teutonus (Schrank, 1781) & $\mathrm{E}$ & & & & & 1 & & & & & \\
\hline Syntomus obscuroguttatus (Duftschmid, 1812) & A & & 14 & 1 & & & & 4 & 2 & & \\
\hline Syntomus truncatellus (Linnaeus, 1761) & E & & & & & & & & 1 & & \\
\hline Trechus quadristriatus (Schrank, 1781) & $\mathrm{E}$ & 1 & 12 & 31 & 1 & 7 & & 30 & 11 & & 14 \\
\hline Zabrus tenebrioides (Goeze, 1777) & $\mathrm{E}$ & & & & & & & 19 & & & \\
\hline Number of taxa & & 5 & 20 & 31 & 12 & 17 & 7 & 21 & 21 & 11 & 19 \\
\hline Number of specimens & & 13 & 119 & 148 & 34 & 90 & 10 & 119 & 55 & 73 & 130 \\
\hline
\end{tabular}

IS, indication status; T1, 2007; T2, 2008; T3, 2009; T4, 2010; T5, 2011. 
Table 2. Simpson and Shannon-Weaver's index of diversity in years 2007-2011.

\begin{tabular}{lllllllllll} 
Index & \multicolumn{4}{c}{ Conventional farming } & \multicolumn{4}{c}{ Organic farming } \\
& 2007 & 2008 & 2009 & 2010 & 2011 & 2007 & 2008 & 2009 & 2010 & 2011 \\
Simpson & 3.0727 & 9.8409 & 8.5097 & 9.3226 & 6.9349 & 6.25 & 6.8049 & 10.614 & 3.9098 & 6.8643 \\
Shannon & 0.8148 & 0.8621 & 0.7932 & 0.9421 & 0.8004 & 0.9696 & 0.7524 & 0.8881 & 0.7194 & 0.7633 \\
\hline
\end{tabular}

years of monitoring occurred only sporadically but the abundance of which jumped only in one year; i.e., Acupalpus meridianus (26 specimens), Amara bifrons (38 specimens), Amara similata (39 specimens), Calathus fuscipes (37 specimens), Harpalus distinguendus (31 specimens) and Syntomus obscuroguttatus (21 specimens). Lower numbers of hygrophilous species (i.e., those occurring in forests, floodplain sites and/or wetland muddy banks) were trapped as well; viz., Pterostichus niger (1 specimen), Pterostichus longicollis (2 specimens), Pterostichus vernalis (1 specimen), Demetrias monostigma (11 specimens), and Paratachys bistriatus (6 specimens). It is difficult to compare these results with the majority of published data because of difference in sampling techniques (pitfall traps were commonly used). The results obtained in this study indicated that there were no marked differences in numbers of ground beetles occurring in ecologically and conventionally managed alfalfa stands.

\section{References}

ANONYMOUS, 2006 - Decree No. 395/1992, the Czech National Council Act No. 114/1992Sb., The protection of nature and landscape. [In Czech].

ARNDT E., BEUTEL R.G., WILL K., 2005 - Carabidae Latreille, 1802. In: BEUTEL R.G. and LESCHEN A.B. (Eds.), Coleoptera, beetles. Vol. 1: Morphology and systematics (Archostemata, Adephaga, Myxophaga, Polyphaga partim). - Walter de Gruyter, Berlin, New York, pp. 119-146.

ARNETT R.H., THOMAS M.C., 2001 - American beetles. Vol. 1. Archostemata, Myxophaga, Adephaga, Polyphaga: Staphyliniformia. CRC Press LLC, Boca Raton, FL; London; New York, NY; Washington, DC, pp. 32-132.

AUDISIO P., TAGLIANTI A.V., 2011 - Fauna Europaea - Carabidae, version 2.4. Available from: http://www.faunaeur.org Accessed: 11/3/2013.

BOHÁČ J., 1988 - Use of Staphylinid beetles as bioindicators environmental quality. - Newslett. Czech Entomol. Soc. 24: 33-41. [In Czech].

BOHÁČ J., 1999 - Staphylinid beetles as bioindicators. Agric. Ecosyst. Environ. 74: 357-372.

FREUDE H., 1976 - Carabidae. In: FREUDE H., HARDE K. and LOSE G.A. (Eds.), Die Käfer Mitteleuropas. - Goercke \& avers Verlag, Krevele, p. 304.

GRYUNDAL S., 1991 - Carabid beetles (Coleoptera, Carabidae) as indicators of recreative influence on forests. - Proc. 4th ECE/XIII. SIEEC, Gödöllö, pp. 165-167.

HOLLAND J.M., 2002 - The agroecology of carabid beetles. - Intercept, Andover, p. 356.

HŮRKA K., 1992 - Carabidae I. - Academia, Praha, p. 192. [In Czech].

HU゚RKA K., 1996 - Carabidae of the Czech and Slovak Republics. Kabourek, Zlín, p. 566.

HŮRKA K., VESELÝ P., FARKAČ J., 1996 - Use of Staphylinid beetles as bioindicators environmental quality. - Newslett. Czech Entomol. Soc. 32: 15-26. [In Czech].

KOLAŘÍK P., ROTREKL J., BARTÁK M., FECHTNER M., FRYDRYCH J., CAGAŠ B., 2010 - Biodoversity of insects in stands of alfalfa (Medicago sativa L.) in 2008 and 2009. - Úroda Annex Res. 12: 297300 [In Czech].
KULA E., PURCHART L., 2004 - The ground beetles (Coleoptera: Carabidae) of forest altitudinal zones of the eastern part of the Krušné hory Mts. - J. Forest Sci. 50: 456-463.

KULT K., 1947 - The key to determining the ground beetle (Carabidae) of the Czechoslovak Republic. Entomological manuals. Czechoslovak Entomological Society, Praha, 20: 198. [In Czech].

LAROCHELLE A., 1990 - The food of carabid beetles (Coleoptera: Carabidae, including Cicindelinae). Fabreries 5: 132.

LÖVEI G.L., SUNDERLAND K.D., 1996 - Ecology and behaviour of ground beetles (Coleoptera: Carabidae). Ann. Revue Entomol. 41: 231-256.

NIEDOBOVÁ J., HULA V., ŠŤASTNÁ P., 2011 - Ground Beatles (Carabidae) from slopes of macošská strá and vilémovská strá (protected landscape area of Moravský kras, Czech Republic). Acta universitatis agriculturae et silviculturae mendelianae brunensis, 59. - Available from: http://ipm.mendelu.cz/dok_server/slozka.pl? id=51329; download=77580 Accessed: 11/3/2013. [In Czech].

NOVÁKOVÁ L., 2012 - Limestone quarries as a refuge for endangered species of invertebrates - preliminary results. Available from: http:// mnet.mendelu.cz/mendelnet2012/articles/34_novakova_643.pdf Accessed: 11/3/2013. [In Czech].

PULPÁN J., HŮRKA K., 1993 - Carabidae, pp. 12-22. In: JELÍNEK J. (ed.), Check-list of Czechoslovak Insects IV (Coleoptera). Seznam československých brouků. Fol. Heyrovskyana, Suppl. 1: 3-172. [In English and Czech].

PULPÁN J., REŠKA M., 1971 - Vertical and territorial expansion beetle family Carabidae (Coleoptera) in Czechoslovakia. - Acta Musei Reginaehradecensis Ser. A Sci. Nat. 12: 85-104. [In Czech].

ŠARAPATKA B., URBAN J., 2005 - Organic farming, textbooks for schools and practice, 2nd Part. 1 ed. - MŽP ČR and PRO-BIO, Praha, p. 334. [In Czech].

SKOUPÝ V., 2004 - Ground-beetles (Coleoptera: Carabidae) of the Czech and Slovak Republics of Jan Pulpán's collection. - Nakladatelství Public History, Praha, p 213. [In Czech and English].

STUBBE A., TIETZE F., 1982 - Ökologische Untersuchungen an Carabidengesellschaften entlang einer Trasseimmissionsgeschädigter Kiefernforste in der Dübener Heide. - Archiv. Natur. Landschaft. 22: 27-44.

TURIN H., PENEV L., CASALE A., 2003 - The genus Carabus in Europe. A synthesis. [Collective work with checklist, keys, biology \& ecology, etc.]. - Pensoft Publ., Sofia, pp. 536.

THAYER M.T., 2005 - Staphylinidae. In: BEUTEL R.G. and LESCHEN A.B. (Eds.), Coleoptera, beetles. Vol. 1: Morphology and systematics (Archostemata, Adephaga, Myxophaga, Polyphaga partim). - Walter de Gruyter, Berlin, New York, pp. 296-344.

URBAN J., ŠARAPATKA B., 2003 - Organic farming, textbooks for schools and practice, I. Part. 1 ed. - MŽP ČR a PRO-BIO, Praha, p. 280. [In Czech].

VESELÝ P., 2002 - The ground beetles of Prag (Die Laufkäfer Prags). Clairon Production, Praha, p. 167. [In Czech, German abstract].

VESELÝ P., MORAVEC P., STAVOVSKÝ J., 2005 - Carabidae (Ground beetles). In: FARKAČ J., KRÁL D. and ŠKORPÍK M. (Eds.), Red list of threatened species in the Czech Republic Invertebrates. - Agency for Nature Conservation and Landscape of the Czech Republic, Praha, pp. 406-411. [In Czech]. 